\title{
J. Piwowarczyk, Bieda jako wyzwanie duszpasterskie w świetle nauczania Jana Pawta II \\ Kraków 2007
}

\section{Bieda jako moralno-duszpasterskie wyzwanie współczesności}

Chrystusowe słowa: „Albowiem ubogich zawsze macie u siebie...” (Mt 26, 11) wyrażają prawdę wszechczasów, że ubóstwo i bieda są stałym elementem ziemskiej egzystencji człowieka. Historia ukazuje różne formy i postacie ludzkiej biedy, różne też były i są jej nasilenia i okoliczności występowania. Także człowiek doświadczający biedy w różny sposób do niej podchodził, choć prawie zawsze traktował ją jako stan braku i ograniczenie realizacji swoich potrzeb i celów. Także przez innych, biedny człowiek często nie był - nie jest (sic!?) - postrzegany jako szczególnie znaczący czy wartościowy. Bieda jawi się więc jako ten stan i okoliczność ludzkiej egzystencji, która poniża człowieka, spychając go na dalszy plan zainteresowań świata oraz deprymuje we własnej świadomości. Inaczej natomiast biednego człowieka traktuje Bóg; jest to postawa wprost odwrotna. W oczach Bożych biedny jest dowartościowany, staje się szczególnie umiłowany i obdarowywany. Bóg bowiem nie patrzy na człowieka „oczami świata”, a Jego sądy nie są sądami ludzkimi (por. J 7, 24; 8, 15). W tej Bożej perspektywie bieda przyjmuje inny wymiar i inny sens. Trafnie ujął to ks. Jan Twardowski: „Ubogim jest nie tylko ten, kto nie ma pieniędzy. Biedakiem jest ten, kto ma samochód, dolary, domek na lepsze czasy, a brak mu serca, przyjaźni, wiary. Są biedacy, którym wydaje się, że życie im się nie udało, a ich praca jest bezużyteczna. Życie trudne i w naszych oczach zmarnowane może być wypełnieniem Bożych planów".

W tej perspektywie ludzką biedę rozpoznaje i wyjaśnia Kościół. Czyni to w swoim nauczaniu i praktyce życia religijno-moralnego, traktując człowieka biednego i jego sytuację w sposób szczególnie zobowiązujący; choć w historii spotkać można różne praktyczne tego przejawy. Ostatnie dziesięciolecia ukazują jednak coraz większą troskę Kościoła o ludzi biednych, co przejawia się zarówno w oficjalnych wypowiedziach Urzędu Nauczycielskiego Kościoła, jak i w rozwijających się kościelnych formach zaradzania ludzkiej biedzie. Tego rodzaju postawę szczególnie prezentował w swoim nauczaniu i praktycznym zaangażowaniu papież Jan Paweł II. Dobrze się stało, że analizę tej spuścizny Jana Pawła II w wymiarze życia społecznego podjął w swej książce ks. dr Jan Piwowarczyk. Wyrazy uznania należą się temu Autorowi, który w swej koncepcji badawczej i duszpasterskich zainteresowaniach wykazuje wielką wrażliwość 
na najbardziej aktualne problemy współczesnego człowieka i zagrożenia jego osobowej godności.

Omawiana książka ks. Jana Piwowarczyka została wydana nakładem Wydawnictwa Naukowego Papieskiej Akademii Teologicznej w Krakowie jako rozprawa doktorska (Kraków 2007). Całość jej treści licząca 300 stronic tekstu, została podzielona na pięć rozdziałów, które poprzedza „Wykaz skrótów”, „Bibliografia” i „Wstęp”, zwieńczona jest „Zakończeniem”.

We „Wstępie” Autor najpierw dokonał ogólnego wprowadzenia w podejmowaną $\mathrm{w}$ pracy problematykę, aby $\mathrm{w}$ ten sposób przybliżyć to zagadnienie w rozumieniu i interpretacji nauki społecznej papieża Jana Pawła II. Następnie sformułował problem rozprawy, uzasadniając jego treść i cele badawcze. Wyjaśnił też terminologię i pojęcie zbliżone do podejmowanych $w$ analizie oraz te, które wyrażają jej istotę. We „Wstępie” mamy też omówienie dotychczasowego piśmiennictwa na tematy zawarte w rozprawie, co pozwoliło Autorowi bardziej sprecyzować zagadnienie niniejszej rozprawy i jego merytoryczne uzasadnienie. Po wskazaniu zastosowanej w rozprawie metody badawczej ukazany został układ treści całości prowadzonych analiz i wniosków.

Rozdział pierwszy został zatytułowany „Różne oblicza biedy”. Ksiądz J. Piwowarczyk ukazał tu przegląd poglądów i przejawów biedy w perspektywie historycznej i społeczno-politycznej. Najpierw omówił starożytne określenia biedy, następnie scharakteryzował średniowieczną biedę jako brak należytego dobra. Kontynuując ten historyczny przegląd ukazał rozwój pojęcia biedy w odrodzeniu i oświeceniu oraz biedę klasową epoki przemysłowej XIX wieku. W ostatniej części tego rozdziału spotykamy charakterystykę polityczno-społecznych aspektów biedy współczesnej. Kontynuacją tego historycznego przeglądu analizowanego problemu biedy jest rozdział drugi. Nosi on tytuł „Nauczanie Kościoła na temat biedy”. Autor koncentruje się tu na myśli teologicznej i odniesieniach Kościoła do problematyki biedy. Analizy swoje rozpoczyna od ukazania biblijnego pojęcia biedy w Starym i Nowym Testamencie oraz nauki ojców Kościoła „o biednych i ich potrzebach”. Kontynuując analizę poglądów i praktyk Kościoła wobec biedy i biednych scharakteryzował średniowieczną i trydencką formę pomocy biednym oraz dyskusje tych okresów historycznych wokół tego zagadnienia. W kolejnym punkcie skupił się na analizie biedy jako problemu społecznego w nauczaniu papieży do II Soboru Watykańskiego. Zapoznanie się z tymi dokumentami pozwala Autorowi ukazać myśl Vaticanum II w tym względzie. $\mathrm{W}$ ten konsekwentny sposób dochodzi do uświadomienia biedy współczesnego świata, co jest szczególnym przedmiotem zainteresowania papieża Jana Pawła II. Rozdział ten kończy charakterystyka różnych postaci i form biedy w nauczaniu tego papieża, co stanowi główny problem omawianej rozprawy.

W rozdziale trzecim pt. „Opcja preferencyjna na rzecz ubogich” ks. J. Piwowaryczyk rozpoczyna merytoryczną analizę biedy jako problemu etyczno-społecz- 
nego. Najpierw koncentruje się na ludziach biednych jako problemie etycznym oraz ich miejscu w panoramie społeczno-ekonomicznych problemów współczesnego świata. W kolejnym punkcie swych analiz zatrzymuje się na biednych jako „bazie społecznej teologii wyzwolenia”. Ukazanie tej charakterystycznej perspektywy widzenia biedy pozwala bardziej wyeksponować rozumienie opcji preferencyjnej na rzecz ubogich przez Jana Pawła II. Rozwijając tę problematykę wykazuje, że opcja preferencyjna na rzecz ubogich stanowi zasadniczą ideę moralności społecznej Kościoła.

Czwarty rozdział omawianej rozprawy został poświęcony normatywnemu wymiarowi analizowanej problematyki. Nosi on tytuł „Solidarność z biednymi jako zobowiązanie społeczne według Jana Pawła II”. Uzasadniając ów normatyw społeczny, jakim jest bieda, ks. J. Piwowarczyk najpierw ukazał chrześcijańskie rozumienie solidarności oraz rolę i znaczenie katolików w tworzeniu jedności wspólnoty ludzkiej. Następnie podkreśla, że dobra wspólne stanowią przedmiot społecznej solidarności. Źródłem zaś moralnego zobowiązania w tym względzie jest przykazanie miłości bliźniego, które wobec biednych stanowi szczególny wymóg społecznej moralności. Rozdział ten kończy charakterystyka wyobraźni miłosierdzia, jaką prezentuje w swoim nauczaniu i postawie życiowej papież Jan Paweł II.

Ostatni - piąty rozdział swej pracy ks. J. Piwowarczyk poświęcił praktycznym formom zaradzania biedzie współczesnego świata. Zagadnienie to ujmuje w kategoriach pastoralnych, stąd tytuł tego rozdziału brzmi: „Duszpasterstwo wobec biednych". Analizy tego zagadnienia rozpoczyna od ogólnej charakterystyki pomocy charytatywnej chrześcijan. Następnie koncentruje się na apostolstwie miłosierdzia we wspólnocie parafialnej oraz instytucjonalnych formach pomocy biednym. Rozszerzając wizję potrzeb i możliwości posługi w tym względzie ukazuje wezwania Kościoła do pomocy międzynarodowej, podkreślając, że miłosierdzie jest naturalną misją Kościoła.

W „Zakończeniu” Autor dokonał podsumowania całości przeprowadzonych analiz, wskazując charakterystyczne wnioski stąd płynące. Wskazał miejsce i znaczenie nauczania społecznego Jana Pawła II w zakresie całej nauki społecznej Kościoła, koncentrując się na podjętej w pracy problematyce biedy. Wyeksponował też wkład i oryginalność tego papieża w interpretację tej problematyki oraz jego koncepcję pomocy ludziom biednym zarówno we wspólnocie Kościoła, jak i ogólnoludzkiej.

Poznanie treści pozwala ocenić metodologiczną i merytoryczną wartość rozprawy ks. J. Piwowarczyka. Podjęty tu problem jest w pełni zasadny, aktualny i wymagający pogłębionej analizy teologicznej. O aktualności podjętego w tej pracy zagadnienia najlepiej świadczy fakt, że w roku 2006 Nagrodę Nobla Muhammad Junus otrzymał „za walkę z biedą”. Samo pytanie problemowe omawianej rozprawy jej Autor sformułował jasno i jednoznacznie: „W jaki 
sposób Kościół pontyfikatu Jana Pawła II podjął wyzwanie jakim jest istnienie w świecie współczesnym wielkich obszarów biedy?”. Podejmując odpowiedź na tak sformułowane pytanie ks. J. Piwowarczyk zakłada sobie konkretny cel, jakim jest „ukazanie problematyki biedy w świetle nauczania społecznego Jana Pawła II”. Zarówno więc merytoryczny zakres problematyki, jak i źródła rozprawy są jednoznacznie określone i nie nasuwają żadnych wątpliwości.

Metodologiczne podejście Autora do rozwiązania tak sformułowanego zagadnienia charakteryzuje się swoistą oryginalnością, co nadaje tej pracy szczególną wartość. Ksiądz J. Piwowarczyk prowadzi swe analizy przez odwołanie się do metody personalistycznej, której podstawową zasadą hermeneutyczną jest osoba ludzka brana w swej ontologicznej i egzystencjalnej złożoności. Od strony formalnej, metoda ta pozwala ująć doświadczenie osobiste jako doświadczenie wspólnoty osób (Boga i człowieka) zarówno w wymiarze wertykalnym, jak i horyzontalnym. Na płaszczyźnie epistemologicznej, podejście personalistyczne umożliwia opisanie i zidentyfikowanie przeżycia biedy przy użyciu niektórych metod fenomenologii. Od strony analizy treści podjętej problematyki, pozwala ukazać kolejne fazy myślenia naukowo-twórczego, takie jak: weryfikacja fenomenologicznie opisanego zjawiska i przeżycia biedy, jego obiektywizacja w świetle danych Objawienia i nauki Kościoła oraz ustalenie praktycznych norm aktualizacji życia moralnego człowieka w badanym aspekcie. Zastosowanie tej metody pozwoliło Autorowi uniknąć subiektywnych interpretacji i dokonać ciekawego opracowania wzrostu człowieka w postawie miłosiernej posługi na rzecz ludzi biednych. W ten sposób wzbogacił on dotychczasowe metody naukowych badań problematyki biedy w zakresie teologii.

Merytoryczna wartość ocenianej monografii ks. J. Piwowarczyka wyraża się w pogłębionej analizie teologicznej interpretacji istoty biedy w chrześcijańskim rozumieniu oraz jej normatywnego znaczenia w życiu Ludu Bożego. Stanowi to też próbę nakreślenia zarysu teologii biedy i doświadczeń człowieka w tej kwestii w kontekście nauczania Kościoła oraz religijno-moralnego życia tej wspólnoty. Mając na względzie dane Objawienia oraz doktrynę Kościoła zwłaszcza nauczanie Jana Pawła II - Autor zaprezentował merytoryczne i treściowe podstawy chrześcijańskiej myśli i działań związanych z „obecnością” biedy w świecie oraz praktycznych postaw wobec tego zjawiska. Tym samym ks. J. Piwowarczyk podkreśla, że fakt i zakres oraz formy współczesnej biedy stanowią fundamentalne wezwanie skierowane do każdego chrześcijanina oraz wyznaczają zasadę życia całego Ludu Bożego. Jako normatyw moralny bieda ma swój przedmiot i podmiot, a urzeczywistniany jest on w poszczególnych czynach, posiadających swe konkretne postacie i formy. Rozumienie i realizacja owego normatywu winne być dostosowane do sytuacji i uwarunkowań życia ludzi danego czasu i miejsca. Tak pojmowana normatywna postawa wobec biedy 
jawi się jako charakterystyczna rzeczywistość religijno-moralna, stanowiąca przedmiot pogłębionej analizy teologicznej.

Ksiądz J. Piwowarczyk, analitycznie pochylający się nad problematyką biedy w refleksji i życiu Kościoła słusznie dochodzi do wniosku, że problem ten i jego normatywny wymiar mogą stać się zrozumiałe dla współczesnego człowieka tylko w kontekście refleksyjnego doświadczenia jego własnej egzystencji - niepokojów i zagrożeń. Lektura pracy pozwala zrozumieć, że teologicznomoralna i pastoralna refleksja nad ludzką biedą nie może być wyłącznie wykładem abstrakcyjnych treści dotyczących teorii tego fenomenu, ale ma ukazywać analityczny obraz dziejowej rzeczywistości Bosko-ludzkiej, wpisanej w egzystencję konkretnego człowieka. Przedmiotem tak pojmowanej teologicznej analizy, z jednej strony jest człowiek z całą wewnętrzną prawdą swej egzystencji, $\mathrm{z}$ drugiej zaś Bóg w swoim miłosierdziu, w którym człowiek - poprzez specyficzne przeżycie prawdy swej egzystencji - poznaje Boga i człowieka nie tylko pojęciowo, ale spotyka ich w specyficznym obrazie jedności. Takie zwrócenie się ku osobie ludzkiej doświadczającej biedy pozwala - zdaniem Autora omawianej pracy - zrozumieć jej egzystencjalną sytuację w kontekście najbardziej pierwotnego związku z Bogiem żywym - Ojcem miłosierdzia. W konsekwencji prowadzi to do podjęcia wysiłków na rzecz zaradzenia biedzie i pomocy potrzebującym jako fundamentalnej zasadzie tworzenia wspólnoty i prawidłowych relacji międzyludzkich.

Przeprowadzone przez ks. J. Piwowarczyka analizy i refleksje bogatej w treści i wieloaspektowej problematyki biedy i zaradzania jej we współczesnym świecie oparte zostały na Objawieniu, Tradycji i nauczaniu Kościoła, czyli na podstawowych źródłach teologicznych. Wykorzystana zaś literatura przedmiotu pozwoliła Autorowi poszerzyć ową refleksję w kontekście innych nauk oraz ludzkiego doświadczenia. Takie podejście do problemu rozprawy gwarantuje źródłową i eklezjalną wiarygodność prowadzonych analiz oraz merytoryczną wartość wniosków. Na tle historycznego rozwoju teorii i praktyki Kościoła wobec biedy, prezentowana przez ks. J. Piwowarczyka moralno-pastoralna koncepcja interpretacji biedy w ujęciu Jana Pawła II nacechowana jest personalistycznym odniesieniem do człowieka, z poszanowaniem jego godności i potrzeb. Takie rozumienie chrześcijańskiej posługi wobec ludzi biednych oczyszcza ją $\mathrm{z}$ historycznych uwarunkowań, które wielokrotnie zniekształcały naturę i egzystencjalne znaczenie społecznej nauki Kościoła i jego miłosierdzia.

Uważna lektura tej interesującej rozprawy pozwala dostrzec też pewne jej cechy, które nasuwają pytania. Charakterystyczna wydaje się swego rodzaju dysproporcja w podziale treści. Otóż dwa pierwsze rozdziały - choć treściwe merytorycznie - swoiście wykraczają poza zakres pracy zapisany w tytule: ...w świetle nauczania spotecznego Jana Pawta II. Wprawdzie bardzo dobrze się stało i w pełni zasadnym jest historyczne wprowadzenie w tematykę wyzna- 
czoną w tytule, ale jakby za duży wydaje się być sam "gatunkowy ciężar” owego wprowadzenia, zajmującego aż dwa rozdziały, czyli prawie jedną trzecią część całości pracy. Tego samego rodzaju „wykroczenie poza tytuł” spotykać też można i w pozostałych rozdziałach, np. w rozdziale czwartym, zatytułowanym wprost „Solidarność z biednymi jako zobowiązanie społeczne według Jana Pawła II”. Podobną tendencję „wykroczenia” wykazuje rozdział drugi, który nosi tytuł „Nauczanie Kościoła na temat biedy”, a pierwszy punkt to: „Biblijne pojęcie biedy w Starym i Nowym Testamencie". W tym samym też rozdziale, w punkcie piątym zatytułowanym „II Sobór Watykański o biedzie współczesnego świata”, na kilku stronicach Autor podejmuje analizę - merytorycznie bardzo rzeczową - posoborowych dokumentów papieża Pawła VI. Z pewnością owe „poszerzenia" podejmowanej problematyki stanowią ubogacenie jej meritum, tylko może samo uporządkowanie owych treści mogłoby przyjąć inną formę. Ciekawość czytelnika jest nie do końca zaspokojona uzasadnieniem moralnego normatywu, jaki wyznacza bieda. Stan i etyczne „nasilanie się” zjawiska biedy domaga się podania bardziej pogłębionego uzasadnienia owej powinności od strony teologicznomoralnej. Wydaje się, że chrześcijanie winni poznać najgłębsze źródła zapisanego tam „zobowiązania” do solidarności z biednymi, a nie ograniczać się tylko do „Przykazania miłości wobec biednych”. Z całą odpowiedzialnością należy jednak podkreślić, że postawione tu pytania i wyrażone wątpliwości nie naruszają zasadniczego układu pracy oraz nie umniejszają jej podstawowych wartości merytorycznych.

Strona formalna ocenianej rozprawy ks. J. Piwowarczyka budzi uznanie dla jej Autora. Prowadzone analizy i wnioski wyrażane są w ,jasnym” i precyzyjnym języku, zrozumiałym nie tylko dla teologa. Lektura tej rozprawy przekonuje, że jej Autor stara się swe myśli wyrażać nie tylko w sposób „czytelny” dla wszystkich, ale też odwołuje się do słownictwa i twierdzeń wielu nauk humanistycznych, co ubogaca wypowiadane treści. Styl wypowiedzi oraz poprawność gramatyczna nadają całości tekstu wartość zachęcającą do lektury. Autor odwołuje się do bogatej literatury związanej z jego problemem badawczym; dużym ubogaceniem jest też wykorzystana w pracy literatura obcojęzyczna. Wykorzystanie całości literatury charakteryzuje analityczne podejście do tekstu, badawcza konsekwencja i trafny dobór poszczególnych pozycji do podejmowanych zagadnień.

Wnikliwa lektura rozprawy ks. dr. J. Piwowarczyka pozwala stwierdzić, że przedstawia ona wysokie walory metodologiczno-merytoryczne i przydatność we współczesnych poszukiwaniach duszpasterskich. Autor podjął w niej bardzo ważny teologicznie i aktualny problem, oraz wartościowo merytorycznie go uzasadnił. Szczególną wartość tej monografii stanowi zastosowanie personalistycznego podejścia do zagadnienia biedy we współczesnym świecie, co pozwoliło Autorowi ukazać merytoryczną głębię tego zagadnienia i humanitarne sposoby jego rozwiązywania. Niezwykle cenne jest też uwyraźnienie eklezjalnego i pa- 
storalnego wymiaru analizowanego problemu biedy, wobec której podkreślono diakonijną postawę całego Kościoła i każdego chrześcijanina. W charakterystyce zaś realizacji owego normatywu Autor słusznie wyeksponował wartość osoby i jej dobro, wyrażające się w trosce o aktualne potrzeby człowieka oraz kształtowanie wyobraźni miłosierdzia jako wymogu na przyszłość. Główny problem pracy został dobrze usytuowany zarówno w kontekście historycznym, jak też na płaszczyźnie przemian i zagrożeń współczesnego świata, ukazując chrześcijańską postawę miłosiernej posługi jako jeden z niezwykle ważnych sposobów zaradzania biedzie. Przedstawiony przez ks. J. Piwowarczyka obraz pasterskiej posługi Kościoła wobec biedy współczesnych ludzi jawi się nie tylko jako zasada ogólno-chrześcijańska (wymiar ekumeniczny), ale też postawa życiowa, która winna charakteryzować wszystkich ludzi.

Wymienione tu walory omawianej książki ks. Jana Piwowarczyka winny zachęcać do lektury tej interesującej pozycji. Godna jest ona polecenia nie tylko zajmującym się teologią i duszpasterstwem, ale też wszystkim wrażliwym na biedę drugiego człowieka i wykazującym potrzebę pomocy w tym zakresie. Do tego zaś są wezwani i zobowiązani wszyscy ludzie, a zwłaszcza chrześcijanie, do których św. Paweł zwraca się słowami: „Jeden drugiego brzemiona noście i tak wypełniajcie prawo Chrystusowe" (Ga 6, 2).

Ks. Józef Zabielski Uniwersytet $w$ Białymstoku 